\title{
Jakobson and Peirce: Translational intersemiosis and symbiosis in opera
}

\author{
Dinda L. Gorlée \\ Van Alkemadelaan 806, NL-2597 BC \\ The Hague, The Netherlands \\ e-mail: gorlee@xs4all.nl
}

\begin{abstract}
Metalinguistic operations signify understanding and translation, specified in Jakobson's varieties of six language functions and his three types of translation. Both models were first presented in the 1950s. This article is rooted in Jakobson's models in connection with Peirce's three categories. Bühler's three functions with qualitative difference anticipated, perhaps not accidentally, Jakobson's distinctions indicating qualitative difference within literary forms and structures as well as other fine arts. The semiotic discovery, criticism and perspective of elements and code-units settle the numerical differences as well as the differences in realistic messages and conceptual codes. Jakobson's intersemiotic translation is updated in vocal translation, which deals with the virtual reality of opera on stage, reaching a catharsis of the operatic mystique. The word-tone synthesis of opera (or semiosic symbiosis) will demonstrate the typological unification of verbal and nonverbal languages.
\end{abstract}

\section{Jakobson's translational paradigm}

Language - that first and supreme tool which homo (man and woman) as a fabricator of linguistic and cultural projects shapes to communicate, to teach, and to command - employs as two essential tools visual (graphemic) features for fixing within written texts, and sonic and tactile features (words, looks, gestures) used in oral interpreting. Both spoken and written messages, plus the accompanying paralanguage, can be translated semiotically, and equally referred to 
nonverbal languages. All current work about the different combinations between linguistic and non-linguistic texts - Jakobson's intersemiotic translational work - is rooted in his own almost classical diagram about the three kinds of "interpreting a verbal sign" distinguished as divided but correlated forms of translation:

1) Intralingual translation or rewording is an interpretation of verbal signs by means of other signs of the same language.

2) Interlingual translation or translation proper is an interpretation of verbal signs by means of some other language.

3) Intersemiotic translation or transmutation is an interpretation of verbal signs by means of signs of nonverbal sign systems. (Jakobson 1959: 233)

Jakobson's threefold division of translational expressions in literary (poetic) form gives the term translation extralinguistic horizons (Gorlée 1994: 147-168; 1997: 240-244; 2005b: 34-35) beyond "translation proper" (Jakobson 1959: 233). The wider phenomenon including "unconventional" forms of translation is either supported by non-semiotic translation theoreticians (e.g., Sager 1986: 331) or often rejected as being non-empirical (e.g., Koller 1992: 82ff.). The pros and contras will, with an ongoing wider acceptance of semiotic methodology, lead to a generalized acceptance of Jakobson's three types of translation.

Jakobson's diagrammatical structure represents a sign that reflects the relational structure of translations. In the $1950 \mathrm{~s}$, intralingual, interlingual, and intersemiotic translations were new theoretical possibilities of understanding a text-sign. Intralingual translating is "the replaced and replacing entities being functions of two variants within one and the same natural language, whether free (e.g., in a definition) or bound (i.e. belonging in two complementary subsystems of that language, such as two registers, two historical layers, or two stylistic types)" (Toury 1986: 1113). It is exemplified by the rewording of summaries and paraphrases, including the re-interpreting, re-editing, amplifying, condensing, parodying, commenting, restyling, rephrasing, and retextualizing form

1 The triadic division of On linguistic aspects of translation (1959) had already been anticipated by Jakobson and introduced in brief terms in his inaugural address to a conference of anthropologists and linguists at Indiana University in 1952 (Jakobson 1971b: 566). See note 10. 
and contents of original source texts. ${ }^{2}$ Interlingual translation is "the two codes being two different, independent natural languages" and intersemiotic translation is "the two codes being two different sign-systems, whether one of them is verbal or not" (Toury 1986: 1113). Intralingual translation is a monadic activity, due to its one-language-oriented equivalences of flexible code-units. Intralingual translation, the conventional translation proper, is dyadic, since it involves two-language-orientedness (or three-or-more-language-orientedness). It stands for a kind of warfare or conflict, embodying a contradiction between Saussurean langue and parole. Interlingual translation is a re-encounter between textual and verbal "reality" in the colloquial sense of the human orientation to reality. The "intermediate" interlingual translation is not as close or clear as intralingual translation, nor as ambiguous or unclear as the understanding of meaning in intersemiotic translation. Intersemiotic translation is sequentially triadic (or more complex), since it involves the union of intermedial translations into an embedded one. ${ }^{3}$

The differences between intralingual, interlingual, and intersemiotic translation are time/space differences without any internal habitat, but still based on the mood, fashion, and taste of the social consensus (responding to Peirce's finite and infinite community). The central presence is abstracted from the intuition, perception or cognition of the translator, but no objective reality (that is, the concept of appearance of the outside world) is available (Gorlée 2004b: 224$225)$. The process and effect of the translator is subjective and egocentric. The translation is free and multi-purpose; it could be performed in any present in changeable time, or located in any time. Meanwhile, translation is restricted by cultural - commercial, political, and religious - values and forces, which inform the translators about the yes/no choices that must be made, and by the

2 For example: translating encyclopedia items and articles on cloning and DNA to school children; explaining Nazi propaganda to modern readership; clarifying Biblical text in modern terms; and transposing dialect into normalized language. Examples abound in daily and scholarly life.

3 The three kinds of translation were rather narrowly defined by Jakobson, who was still unconcerned with reverse or inverse operations during the remainder of the 20th century. Now, in the 21 st century experimentations with intermedia and multi-media art became common as artists searched for new expressions. In Jakobson's original terms, the translation of non-linguistic into linguistic textsigns, and the translation of nonverbal signs by means of other nonverbal signs of the same or different language (or "language") is lacking. 


\section{Dinda L. Gorlée}

rules and strategies established by the community in the background. In Jakobson's types of translation we speak of all possible changes, exchanges, and interchanges in time, tenses, and temporal-spatial differences, in order to deal with their free effects on the act(s) of translating text-signs.

Jakobson's 1959 overview of the target text in his types of translation proposed new multimedia effects in the language, still to come. Later, in 1968, Jakobson remarked on the semiotic capabilities of the mixed medium, language:

The exceptionally rich repertoire of definitely coded meaningful units (morphemes and words) is made possible through the diaphanous system of their merely differential components devoid of proper meaning (distinctive features, phonemes, and the rules of their combinability). These components are semiotic entities sui generis. The signatum of such an entity is bare otherness, namely a presumable semantic difference between the meaningful units to which it pertains and those which ceteris paribus do not contain the same entity. (Jakobson 1971a: 707)

Regarding the freedom and lack of freedom of intersemiotic translation, involving codified parts and elements of language, Jakobson added:

A rigorous dualism separates the lexical and idiomatic, totally coded units of natural language from its syntactic pattern which consists of coded matrices with a relatively free selection of lexical units to fill them up. A still greater freedom and still more elastic rules of organization characterize the combination of sentences into higher units of discourse. (Jakobson 1971a: 707)

The flexible radius of intersemiosis was performed and discussed in the focus of Jakobson's symbiosis of painting, film, and other art forms along with expressions in literary form. For Jakobson, language held center stage.

Jakobson's broader situation of translation generates imitations of all kinds and genres, with direct and true (mimetic) and indirect and feigned or manipulative (non-mimetic) insights for the new target readership. His translational overview was anticipated by Auerbach's classic volume Mimesis (1957; German edition 1946, English translation 1953) examining the use of mimetic representation in Western literature. The concept of mimesis was borrowed from visual arts including painting, sculpture, dance, pantomime, and the visual side of acting and theater (e.g., light, decorations, costume, make-up, 
gesture and tone of voice). The portrayal of reality is pictured using fragments from literature - from the adventures of Odysseus, the sagas of Roland, Pantagruel, Don Quijote and Sancho Panza to modern writers such as Zola and Virginia Wolf - which Auerbach criticized (or questioned) about their literary mimesis.

Auerbach's Mimesis is characterized as a chronological approach as mentioned in Maran's article (2003: 203), yet Auerbach's focus of the discussions of realism and lack of realism is equally causal, rhetorical, poetic, and typological. Literary iconicity (Nöth 1990: 348349) focuses on the realistic imitation (not the real thing) of different aspects of human inward and outward reality, seen through the daily, intellectual, social, economical, religious, and other conceptions of reality to attract support in the form of faith or belief in the poetic imagery. Auerbach's Mimesis includes examinations of meaningful memory-pictures of persons with love and hate, friendship and hostility, their milieu and surroundings, and even dealt with fanciful dreams and fantasies. Taken from Jakobson's classification, Auerbach's description can be considered a transposition in language or, better yet, a translation of the real thing. ${ }^{4}$

4 Auerbach was born in Berlin (1892) into a Jewish family and studied Romance languages at German universities. In his early work, he was sad and depressed by the fate of European civilization (Dirda 2007). Mimesis was his classic (pre-semiotic) manual about classical and modern realism written by in Istanbul, where he lived as a Jewish emigré during World War II. He designed and proceeded this significant study in Turkey, where as he wrote in the epilogue of Mimesis, "the libraries are not well equipped for European studies. International communications were impeded; I had to dispense with almost all periodicals, with almost all the recent investigations, and in some cases with reliable critical editions of my texts" (Auerbach 1957: 489). Auerbach's intellectual situation was startling, but "[s]ome guiding ideas began to crystallize, and these I sought to pursue" (1957: 489). Auerbach survived the Holocaust and emigrated to United States, where he published his semiotic history of the literary sign in "'Figura", the title enclosed with quotation marks (Auerbach 1959: 1176) as a comprehensive folding of outline, imprint, copy, allegory, prefiguration and other terms to show the authenticity of the "art of hinting, insinuating, obscuring circumlocution, calculated to ornament a statement or to make it more forceful or mordant" (Auerbach 1959: 27). His mercurial story resembles Jakobson's geographical and political "alienation" from his native Eastern Europe, and was in those days a sad but general "policy" for the Jewish intelligentsia. Auerbach's biography anticipates the modern literary criticism of the later Barthes and the schismatic and doctrinal unity of structural semiotics. 
Intersemiotic translation is the decentering of verbal language to transpose it into nonverbal languages (Gorlée 1997: 240-244; 2005b: $38-42),{ }^{5}$ and in those days new project of the productive implications, both theoretical and practical, of general semiotics for humanistic studies. Intersemiosis was understood by Jakobson to refer to the oneway metalingual operation in which linguistic signs are creatively transposed or recodified into nonlinguistic codes and elements. Jakobson's famed passage of 1960 artistic examples reads:

We can refer to the possibility of transposing Wuthering Heights into a motion picture, medieval legends into frescoes and miniatures, or L'après-midi d'un faune into music, ballet, and graphic art. However ludicrous may appear the idea of the Iliad and Odyssey in comics, certain structural features of their plot are preserved despite the disappearance of their verbal shape. The question whether Blake's illustrations to the Divina Commedia are not adequate is a proof that different arts are comparable. The problems of baroque art or any other historical style transgress the frame of a single art. When handling the surrealist metaphor, we could hardly pass by Max Ernst's pictures or Luis Buñuel's film, The Andalusian Dog and The Golden Age. (Jakobson 1960: $350-351)$

The creative side of intersemiotic recoding presupposes the improvised desire and free will (on the part of the receptor) translations from the meaning of written signs of a verbal language into a language in a mixed, metaphorical manner of speaking; see visual languages (e.g., plastic arts, painting, sculpture, computer language, architecture, and photography), kinesic languages (e.g., ballet and pantomime), auditive languages (e.g., music and song) and intermedial languages (e.g., cinema and opera).

If music, painting and dance movements may be considered for "study", they are essentially private sensations, expressed publicly to the environment but in and of themselves asserting nothing from a semiological viewpoint. Their performance (see the mixed "narrative" of a sculpture, a film, or an opera) consists of a mixed iconic-indexical sign-event. Thereby a distinction between the sign and its object is drawn, providing a represented meaning and a cultural norm. The

With help from Auerbach's Mimesis I wrote about signs of magic in Don Quijote (Gorlée 1988).

My explanation develops the argument in Gorlée (2004a: 55-56) and is a brief excursion to work of specialists in intersemiotic translation: Plaza $(1985,1987$, 1991) and now the work of Torop $(1995,2000,2003)$. 
source (language) signs and the different target signs (of "language") must be intuitively sensed and cognitively interpretable, thus presupposing codes of communication and hence general signs. This procedure of observing artworks must somehow be built on an amalgamation in language of meaningful sounds and sound sequences, corresponding to morphemes, words, word combinations, sentences, paragraphs, and other endocentric and exocentric elements of verbal language, thus enabling their mutual transcodification into the metaphorical similarity of iconic and indexical "engineering" of artistic expressions. The intersemiotic artist searches for the purity of the verbal and nonverbal signs and attempts to transpose them into modernity, in different times and spaces. This intersemiotic discovery is a phenomenon for scholarship to (self-)question the center of the poetic sign and its accessories and the intermedial languages vs. extramedial languages, that is from inside to outside the sign itself to their environment.

The semiotic status of various nonverbal languages and their equivalences with verbal languages presents problems. The function of the linearity of speech and script must also be defined in the variety of different arts, because written and oral texts are interpreted as unduly narrowing the field of artistic frames. This narrowing presents a distinction and succession of items which in the finished message of painting, architecture, and sculpting is presented all together in the combined sign, Peirce's "emotion of the tout ensemble" (CP 1.311). By surfing to the narration in drama, film and opera we jump from the whole to details, and have a complex series of close-up, medium, and long shots. The chainlike sequence of dramatis personae in written texts is segmented and transposed into different time-space units and sequences (Merrell 1992). Linguistic features are essentially arbitrary and basically conventional(ized) from one language to another, this linguistic process is also true for the perception of music, while the outward manifestation of other arts, such as painting and sculpture, is free to be inspected or neglected at will.

Naming and grouping verbal texts and the basis of the classification of verbal arts should also be considered (Munro 1969). In verbal arts the content is primarily addressed and dealt with, not the medium, materials and instruments. Instead of a written text-sign, we employ a variety of processes and techniques in other arts, the nature of the products so as to form a mode, system, or organization in space 
and time, functioning as a fused mode of participation. The resulting intermedial groups and divisions overlap and we see that some arts are classed together in certain skills, some arts are not. Indeed, in written texts different genres such as aesthetic, moral, spiritual, or other value quality are implied. To explain the fusion of intersemiotic translation, the intertwined functions of source and target texts should be studied in a holistic framework. This transdiscipline is found in transdisciplinary (that is, semiotic) doctrine and terminology. It offers the artist and investigator a commonness of one comprehensive terminology and one set of concepts (somewhat differing in the semiotic schools of Bloomington, Paris, and Tartu) and brings the language and arts together.

One common feature shared by musical and poetic language alike is the role of repeated projection of paradigmatic (that is, structural) equivalences upon the syntagmatic (that is, serial) chain of signs. In music, the organic synthesis of synchronism and progression produces melody, harmony, as well as polyphony, both in language concorded with music, as well as other arts. Another feature is that the arts are constantly overlapping, merging, and redividing, so that new artistic forms emerge and disappear. This happens in a postmodern style, in which different art forms abound (such as the symbiosis of literature and poetic art combining in visual poetry). New subdivisions appear, such as the computerized union of the visual, auditory, and tactile media, thereby marginalizing the increased reliance and confidence of verbal texts into other "untouchable" arts. The decline in literary form and the augmentation of pictorial and symbolic events makes a revolutionary shift from traditional browsing through the fragments of the book towards the continuous narrative of the computerized code without real pages, and moving towards squinting the momentous glance as exemplified in the observation of performances of theater and opera.

The following common characteristic is that all nonverbal codes enumerated above are artistic codes (plastic, musical, and so forth). The translation of natural languages into artificial languages concerning both the acoustic, optical, and tactile fields (such as computer language, Morse code and the Braille system) is an extended speech procedure involving units with only a single articulation. Such code units must, in the strict sense, be considered non-signs, because they are typically based on one-to-one equivalence. Lacking interpretive 
freedom on the part of the new target receiver, non-signs fall outside the scope of intersemiotic translation as it is approached here: that is, as generating Peircean interpretants which, somewhat paraphrasing Peirce's definition, are equivalent to the primary, verbal signs, or possible more developed secondary (that is, translational) signs (CP 2.228 ), giving a creative chance to the mood and taste of the spectators and audiences.

The partnership between the verbal and musical arts (the aim of this essay) is heralded by the earlier Prague School and hinges upon Jakobson's concept of "poeticalness" (Jakobson 1960) in language: the pre-eminence of the poetic function (emphasizing the message as such, for its own sake) over the referential (focusing on the cognitive, informational aspect of language). While the poetic function finds its purest manifestation in poetry, yet without being confined to it, poetry is for Jakobson primarily (but not exclusively) a "figure of sound" (Jakobson 1960: 367): it contains musical elements which are unresistant to seeking a further expansion outside music. These elements include: sound texture, metrical pattern, rhyme structure, alliteration, and phrasing. Together they form what Jakobson called the "internal nexus between sound and meaning" (Jakobson 1960: 373), characteristic of poetic language as opposed to referential language. Jakobson stated that "[i]n referential language the connection between signans and signatum is overwhelmingly based on their codified contiguity, which is often confusingly labeled "arbitrariness of the verbal sign"” whereas sound symbolism is "founded on a phenomenal connection between different sensory modes, in particular between the visual and auditory experience" (Jakobson 1960: 372).

Language-music notations and scores are one example. In other arts or crafts other rules and heterogeneities are encountered. The scheme on multimedia communication provided by Hess-Lüttich gives a comprehensive survey of channels of multimedial transmission, modes of structure, and the codes of systemic organization. In multimedia communication, the channels include light wave, soundwave, biochemical, thermodynamical, electro-magnetic, and transmissive nature; the senses are acoustic, olfactory, gustatory, haptical, and optical; the modes are icons, symbols, indices, including symptoms and impulses; and there are verbal, paraverbal, nonverbal, socioperceptive, and psychophysical codes (Hess-Lüttich 1986: 576). The 
semiotic notion of intersemiotic engineering causes the creative fusion of lingual and other arts to form a collaborative union providing

[...] parallelism and alternation, equivalence and opposition, necessity and contingence, compatibility and incompatibility, the result of which being potentially redundant or elliptical, unequivocal or ambivalent, analytical or synthetical, systemic or probabilistical, dynamic or static, coherent or paradoxical, spontaneous or strategic, convergent or divergent, etc. (Hess-Lüttich 1986: 576)

In conjunction with Jakobson's initial remarks, Plaza's work (see note 5), based on Peirce's works, offers a lucid and ludic approach to intersemiotic translation, where intercode is a poetic art or craft, based upon iconicity, and spreading out into indexicality and symbolism. The essential iconicity means that the intersemiotic translation represents its verbal object by virtue of any inherent similarity between them. The quality of this similarity is concerned with the new code and its special characteristics. Rather than endow the investigator with a determinate civic virtue and hence become a virtual-reality drama, the intersemiotic displacement lacks imitation and possesses artistic mimesis. ${ }^{6}$ Plaza called this process transcreation, where the frozen language becomes playfully alive into some heuristically fertile examples, such as cinematic sequences, film shots, pictorial ideograms, and the I Ching. The discussion about intermedial transcodification has been continued by Torop's explanation of intersemiosis as associate from Lotman's school (Torop 1995, 2000, 2003). The theoretical saga discussing intersemiotic translation has hardly begun and opens up valuable possibilities for new ideas and ideals of further research.

Translational-theoretical issues are commonly dealt with by the "traditional" scholars and will develop further from Jakobson's innovative "linguistics and poetics", concentrating not only upon language-only texts and steered clear of the vast and heterogeneous problem area formed by partially verbal phenomena such as comic strips, theatrical performances, lyrics, and libretti, and to some extent the variety of picture-books - all of them visual-narrative narratives, now "popular" in scholarship. Hailing from Jakobson's times, translation studies have moved away from Bible translation and the classical authors and shifting towards new literary domains such as folktales,

6 Returning to Auerbach's "mimesis", as previously mentioned, including note 4. 
detective novels, Western novels, nursery rhymes, among many other forms of popular literature, which were traditionally considered scholarly inferior, almost an infatuation with trash. The canonical text, once a closed system for academic scholarship, has become an open model and subject to examinations in scholarship and elsewhere (about textual canonicity, see Scholes 1992; Gorlée 2004: 31).

\section{Jakobson's and Peirce's metalanguage functions}

Jakobson's intersemiotic commitments follow his constitutive functions of language. He argued that their difference is quantitative, not qualitative - so that art is more complex and a less tractable realm than biology. Jakobson presented both models in the 1950s. His cardinal structure of language functions was exposed with not only definitions but also examples. Jakobson pairwise correlated his functions to Bühler's functions, and here an attempt is made to correlate them to Peirce's categories, though they are not identical with them, neither in number nor in ideas and concepts. Peirce's categorical triad supplements the interaction of Firstness (moodscape), Secondness (worldscape), and Thirdness (mindscape), and is categorized in verbal texts as well as in nonverbal texts, where textual typology creates different creative and doctrinaire maneuvering of the triadic elements of the expressions. Peirce's functions are not in balance, but are continually shifting. This is also true for Jakobson's text typology (discussed in this subchapter), which is also expressed in different media and codes, both linguistic and non-linguistic messages, and refers to cultural messages. ${ }^{7}$

Peirce's three categories symbiotically join together aspects of Firstness, Secondness, and Thirdness. ${ }^{8}$ Peirce's three-way categorio-

7 The analogy must not be pressed too far. Lotman's mechanism of semiosphere retraced Jakobson's functions to generate his continuum of linguistic messages, see Andrews 1999.

Peirce confessed, tongue-in-cheek, that he might be suffering from a disease called "triadomania", namely "the anticipated suspicion that he [Peirce] attaches a superstition or fanciful importance to the number three, and he indeed forces the division to a Procrustean bed of trichotomy" (heading of CP 1.568). The triadic paradigm was found by Peirce in all kinds of phenomena which run the whole gamut from the history of theology, science, physics, biology, and mathematics to 
logy stated that "First is the conception of being or existing independently of anything else; Second is the conception of being relative to, the conception of reaction with, something else; Third is the concept of mediation whereby a first and a second are brought into a relation" (CP 6.32). Firstness consists only of pure potentiality (CP 1.422), which is "predominant in the ideas of freshness, life, spontaneity, freedom" (CP 1.324). Firstness stands for unanalyzed, instantaneous and immediate feeling or emotion. Firstness is direct "suchness", a basic assurance of Peirce's "maybe" (or "maybe not") dependent on nothing else beyond its own qualitative understanding of the sign, which is understood intuitively. Firstness is undivided and undividable oneness, without thought and without analysis. Firstness is experienced in the feeling of acute pain, an electric shock, a thrill of physical delight, the sensation of redness or whiteness, the piercing sound of a train whistle, a penetrating odor, or any other phenomenon which urges total attention without anything else. It is an instantaneous shiver of feeling of the timeless present that runs through the inquirer's human experience, including the mind of the text-user and translator.

Firstness means undividable oneness, but Secondness is dynamic motion, offering the specific "here and now" assurance of otherness, of two-sided consciousness. Secondness thinks about details of manysided actuality; it sets events into action and reaction as a response to a stimulus, which may cause a change of state from Firstness to movement. Secondness is "hard fact" and "brute opposition" as found in stimulus and response, chance and resistance to change. The existential idea of hitting and getting hit is a Second, since it deals with the forces of the world around us. A Second is the true sign of reality. We experience it in making a phone call, opening a door, kicking a football, etc. Within Seconds, we orientate ourselves in time and space and live past experience in the present. Firstness was "a mere idea unrealized" and Secondness "the cases to which it applies" in reality (CP 1.342). Yet Thirdness is the regularity of feeling and action by general rules providing ultimately logical explanations. All intellectual activity is a Third. It provides order, law, and habit that create their own references for mental growth in the future. Peirce's "habituality" defines the set of

the truth in his theory of signs. Peirce's categories are the focus of my work about translation theory; see Gorlée 1994: 40ff., Gorlée 2004b: 153f.) and other publications. 
previously formed habits, change of habits, and adoption of habits which control the changing activity of human experience with respect to its response to logical stimulus. This is Peirce's "would-be" for the mind of the sceptical text-user and translator.

Thirdness involves bringing "soft" states of pure irregularity and chance of Firstness and the real events and experiments of Secondness together in a "hard" communal and mutual companionship. This doing-and-making process is the hardening laboratory of Peirce's translation. Translation is an evolutionary experiment; its human activity (action of the human sign) manipulates a "sign in actu by virtue of its receiving an interpretation, that is, by virtue of its determining another sign of the same object" and Peirce concluded that the ideal of translation creates " $[\mathrm{t}]$ wo propositions when either might have been an interpretant of each other" (CP 5.569). Translation involves a preexistent text-sign which produces a potentially infinite network of interpretant text-signs. In real time and space, the translated interpretants share relevant properties with their primary text-sign, but also can be radically different from it, or take an intermediate position and stand in an existential or physical connection to it. The source text and target text experiment with the space of knowledge between textinternal and text-external reality ("reality", as discussed), between the creative tension and mutual constraints of the object of the translating and translated texts. In its different stages, translation moves from the intuitive Firstness of moodscape (image), through the Secondness of real worldscape (diagram), to the Thirdness of mindscape (metaphor). In this conscious and subconscious processuality, going from remembrance and perception to anticipation, translation creates for itself more and more referential freedom and space for the creative and doctrinaire maneuvering of meanings. Translation creates both self-referents and referents.

Whereas Firstness rests on the idea of independence and Secondness is the idea of opposition, Thirdness rests on the idea of the complexities of relationship (CP 1.297), a complex friendship with its ups and downs to work on. Among the categorical characteristics of Thirdness are therefore mediation, thought, laws, rules, and habit (CP 1.345f., 1.405f.), all terms meant in the Peircean sense. These symbolic terms are always infinite, borderless, and never fixed. Peirce argues that the dynamical aspects of Thirdness change according to different forms and structures of "reality". Peirce's habit-change is a 
"modification of a person's tendencies" of statement or habit of ideas, force and strength (CP 5.476 f.). The translation formulates the conclusion (CP 5.491). The state of feeling (perception and re-perception) then changes; the action(s) and reaction(s) can also be changed, so as to embody (a) new sign(s) and (a) new meaning(s). This is called habituality, the repeated support of new habits. Semiosis or forceful sign-activity changes with time and space; it entertains successively new doubts, new beliefs, and new persuasions. Under duress of new circumstances a habit-formation cycle is regenerated. The distinctive habits of individuation and classification associated with it fit back into the renewed semiotic process of learning.

The functions of the categories are not in balance; they shift continuously. Each function or factor is multifunctional, their activity moves from one category to the next, extending or narrowing down the meaning of the message. ${ }^{9}$ This contrast of openness and fixedness determining the addresser and the addressee is also true for Jakobson's text typology, which is expressed at face value and in different media and codes, both linguistic and nonlinguistic message. Jakobson's (1960: 353ff.; 1980: 81ff.) ${ }^{10}$ six interactive textual functions supply all the information supported by a message initiated by an addresser, whose destination is an addressee. A good deal of what is communicated, and not communicated, in the text-message depends on the message itself, the code, and the context understood by addresser and addressee.

Briefly synthesizing Jakobson's divisions (without reference to literature), a message (with Jakobson's poetic or aesthetic value of the functions) is the adequate and instructive text-phenomenon, which as

9 Peirce spoke of genuine signs and degenerate signs. This contrast was used by Peirce in two senses. On the one hand, both indexical and iconic signs are considered degenerate with respect to symbolic, fully triadic signs, so that the only sign to be genuine or pure sign is the Third, all of the terms of which are equally Third. On the other hand, both Thirds and Seconds have degenerate forms. In a degenerate Second the Secondness partakes of Firstness. A Third can be degenerate in two degrees. The first degree of degeneracy is found in a Third involving Secondness, whereas the second of degeneracy is found in a Third partaking of Firstness (Gorlée 1990).

${ }_{10}$ Continuation of note 1: Jakobson's functions of messages from his closing statement at a conference on style in 1958 in Bloomington, IN (1960: 353 ff.) were anticipated in his presidential address to the Linguistic Society of America in 1956 (later published in Jakobson 1980: 81 note). 
a cultural text is interesting, puzzling, or disquieting to the addressers. The message is the primary focus of attention, and constitutes the selffocusing palpable sign triggering a response in the audience. It may be a poetic or non-poetic textual wholeness reflecting the pleasure or enjoyment (or depending on the genre, displeasure and alienation) which addressers get from creating social effects through language. Good examples of affecting (and thereby manipulating) the addressees are literary expressions (poems, novels, theater plays), including letters, newspaper articles and advertisements; however, a weather report or a shopping list is rarely kept for later reading. Figures such as sound patterns, diction, rhyme, verbal puns, marked collocations, neologisms, as well as features in other media keep the addressees' eyes and ears open towards understanding the phonemic and graphemic features and visual and sonic qualities of the cultural text.

The addresser or sender (Jakobson's degrees of emotive or expressive value) is not always a person, but often an agent or anonymous voice (like in videoclips) directing a direct expression of his or her emotion or mood to the intended addressees. The addresser's focus lies in connotative fiction, imagination, and aesthetics, both real and fictive. The addresser can be explicit or hidden, that is implicit, when there is no intentional addresser and the message concentrates on the intentions of the context. The context (Jakobson's referential value) contrasts with the addresser's connotation and reflects the denotative content of the message, its cognitive subject-matter. Cultural context is the meaningful reference to the surrounding world and answers the questions, commands, and instructions of the language-user to determine the realism of the message, anchoring the message deictically in real time, space, and events. Content makes sense to the addressee(s) or receiver(s), which may be one person to a multitude.

The addressees (Jakobson's conative value) specify the narrative story of the bodily, behavioral, and psychological influences of the message of the addressers. The message can have a rhetorical value (in love letters, political propaganda, and advertisements). The addressees are subject to a variety of tricks and stratagems of the message to trigger, through its subtle and artistic persuasion, certain behaviors and sensations in the addressees. The contact (Jakobson's phatic value) is the neutral communicational channel, which can be oral, visual, electronic, etc. It offers the informative mindset of the message to possible addressees. The tricks to keep the textual business 
alive between addresser and addressee are the phatic usefulness of an attractive communication for the parties, working through symbols, myths, and ritualized formulas. No harmonious contact means miscommunication, a failure to contact. The primary attention is not on the channel but on the contact between addressee and addresser; other channel agents are gestures in phatic greetings or signs of sympathy with no content. ${ }^{11}$

The metalingual code (Jakobson's glossing value) deals with the formal and normal facts of the orientation towards language or a linguistic system (or subsystem) used in the message. The same linguistic and cultural code (dialect, idiolect, speech, numbers, symbols, pictorial concepts, sound formation) must be used by both parties (addresser and addressee), otherwise there is a mishap in interpretation. The correct metalanguage is the synthesis of understanding and translation, distinctive and significative activities which are both conscious (intelligent) and unconscious (intuitive) (Gorlée 2004b). Metalingual operations involve, as discussed by Jakobson (Jakobson 1960, particularly 1980, and otherwise), the understanding of language as a normal element of life and, subsequently, the sophisticated transposition of translation (in case of rewording, translation proper and transmutation). Translation is defined as the controversy between known and unknown (source and target) texts, the analytic decisions and selections (doing-and-making operations) of the translator, the confrontational-creative attention of the translation with a new reproductional and modificational nature, and the irreversible destiny of the original text, lodged away in a temporary state of forgetfulness (Popovič 1975: 12-13). ${ }^{12}$

11 The phatic signs return to Malinowski (1923, used is a 1969 ed.) and are further discussed in Derrida's The Postcard (1987, tr. 1980).

12 In 1956, Jakobson referred the "traditional model of language" (1980: 83) to Bühler, certainly to contrast with his own new model. Bühler's Sprachtheorie (1990 [1934]) model was confined to three functions: addresser (Ausdrucksfunktion), addressee (appellative Funktion) and context (darstellende Funktion) (Bühler 1990, transl. from 1934). Jakobson built on Bühler's person-oriented model, integrating the "first person of the addresser, the second person of the addressee, and the 'third person,' properly — someone or something spoken of" (Jakobson 1980: 83) Bühler focused on the technical definition of understanding the speech of the receptor(s) listening to the utterer(s), whereas Jakobson's model expanded Bühler's model into a comprehensive structural model, integrating the aesthetic, metalingual and phatic side of speech use. Bühler's model was 
Metatextuality, the common denominator of Jakobson's textmanipulative activities, is rooted in the metalinguistic function, in tandem with the other communicative functions of language. A metalingual text in Jakobson's sense is a verbal text that refers to itself or identifies the code (or sub-code) being used. In translation, this functional modality operates in at least two ways. On the one hand, it exemplifies the fundamental Thirdness of language, its conventional, arbitrary, and hence rule- and culture-bound relation to the possible object in reality; this gives room for manipulative semiotics, i.e., the usage of language with an ideological bias, in which the sign disengages itself from extra-linguistic reality and is granted a referential mobility permitting it to even be used as antithetical and self-referential artifices. On the other hand, metalanguage shows language's capacity for Firstness, i.e., the (degree of) similarity with reference to form, or shape, pattern, or otherwise, between the antecedent text-sign and its consequent interpretations and/or paraphrases, as well as with reference to all text-signs involved and their object in extra-linguistic reality. Through this blend of Thirdness and Firstness through Secondness (the actual instances of the act of translation), the rule for the transformation of the text into its translations is progressively reformulated, thereby becoming steadily more determined. The rule of transactional relativity transpires thus in a constantly moving system, a semiosic adventure.

Jakobson's cardinal functions of language can be pairwise attached or matched to the triad of Peirce's categories, though they are not identical to them and their correlation is interactive and may vary upwards and downwards with the communicational instantiations and textual network. Peirce's Firstness is embodied in the emotive force to introduce sensual expression in the addresser's (sender's) personal(ized) message. Firstness is manifested in the addresser's arbitrary and possible entrée to build the poetry of the desired text. The textual desire must be associated with a regular or relevant language-code utilized by addresser, which we hope is also understood by the addressee. The text must embody cultural (anthropological, sociolo-

qualitative, whereas Jakobson built a quantitative model. Jakobson's expansion gave rise to scholarly controversies, since Jakobson's new functions of language were "borrowed" from pre-World War II sources, like Mukařovsky with regard to his poeticalness and Malinowski with regard to phatic communication (see articles published in Eschbach 1984). 
gical, psychological) values codified in the meaning-potential of the actual message. These cultural clues can be open or hidden. Every generation has, consciously and subconsciously, its own emotional, stylistic and intellectual level. Firstness is dominated by addresser (emotive/expressive value), in the degenerated (debilitated) company of channel, context and code (phatic, referential and metalingual values), in that order.

Secondness is embodied in the adequate and instructive verbalpoetic design of the message in order to function as live communication, as a significant cultural event. Secondness is about something (the topic of the message) and reflects in the narrative an actual message-text, which must be common to the world of both addresser and addressee. The meaningful contextual worlds at hand for both parties (addresser and addressee) generate a realism (real or fictive) of time, place, objects, and cultural events. A common language is understandable for the parties. Secondness is inquired to create a common intertextual world (also real or fictive) with its own possibles and impossibles in order to create unity out of chaos. Secondness is dominated by the message (poetic value) supplemented with degenerated context, code and channel (referential, metalingual and phatic values) in that order.

Thirdness is expressed in the fragile and subtle understanding of the message by possible, actual and virtual audiences (addressees or receivers) with mutual understanding of a definite time and place in all types of language and "languages" used in the message. Thirdness also includes within this community the specific codified actions, interests, and values to reflect the ideology of the addressees in the (non)verbal message. Verbal language can be partially or totally superceded by nonverbal languages. Adding to the creative poetics, the phatic usefulness transmogrifies the message into many text-signs through ritualized formulas to keep communication working and attractive for a sufficient number of addressees in the future. Thirdness is dominated by the addressee (conative/appellative value) and degenerate code, channel, code and context (metalingual, referential and phatic values), in that order.

The Jakobson-Peircean model with combined quantity and quality values results as in Figure 1. 


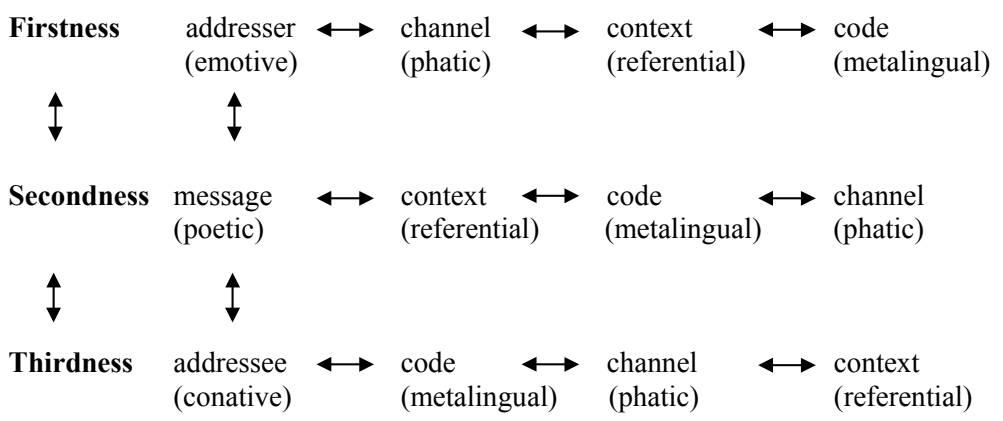

Figure 1. The Jakobson-Peircean model with combined quantity and quality values.

The interactivity of the qualities and quantities results from the dynamics of practice, and is invisible in theoretical models: the shifting of the qualities of legal messages differs from an epistolary novel and from perfume advertisements. In order to test the distinguishing character of an autobiography, we see its differences with a biography, since the author of an autobiography writes his or her own life line and a biography composes the life of someone else (following Lotman 1990). Both autobiography and biography struggle against our forgetfulness, rescuing feelings, actions and thought from our laziness and inertia; Lotman spoke of "mnemonic" signs (Lotman 1990: 21, 27). The signs of an autobiography are "hidden" and provide, to the viewpoint of the writer, a meaningful account of the intimacy, occupation and field of endeavor of himself or herself (First, Second, Third). An autobiography is a personal diary, responding in itself to Firstness, while the biography is a shift to Secondness. An autobiography rests on an emotive background; the addresser writes a personal account with artistic and dramatic qualities (Firstness). The scholarly qualities (Lotman's mnemonic functions) are still weak. An autobiography has a single protagonist, the hero (heroine) of one's own social construction. The biography records the life of the same hero, but is a written account meant for commercial publication, it is not naive but official. The writer attends to his own poetic narratives using key questions asked of the individual. This happens in personal reviews or correspondence or, when the hero is no longer living, by questioning and interviewing family, relatives, friends and colleagues 
about the clues of written accounts or memories, souvenirs, pictures, etc. The author of a biography attempts to construct his (or her) narrative genre reflecting a "new" self about someone else's otherness. The biography includes his or her dramatic, social, and emotional life, according to "new" cultural coordinates. The scholarly qualities are emphasized in the shift to the function of metalanguage. Thirdness is crucial for the referential and expressive value of understanding the intersemiosis to get the message across. The addressee depends on metalanguage, but within intersemiosis the message between sender and receiver can equally focus on other nonverbal "language" elements.

\section{Symbiosis of signs in opera}

One of the advantages of Peircean and Peirce-derived scholarship is its generality. The general ideas, vocabulary and concepts about general signs enable the investigators to deal with linguistic and nonlinguistic texts or messages alike. A written text, as semiotically defined and described in Gorlée 2004b: 17-30, informs the reader differently than the textuality of non-written languages, notably in the media evolution in narrative discourse, where we experience a loss of information (Moulthrop 1991). The general nature of semiotics makes it possible to classify a variable and hence virtual sign system ${ }^{13}$ such

13 Peirce already liked the term "virtual" and anticipated virtual reality, defining it in 1902 in connection to virtual vision. He described it locally as "A virtual X (where $\mathrm{X}$ is a common noun) is something, not an $\mathrm{X}$, which has the efficiency (virtus) of an X" (CP 6.372). The ambiguity of the word rests on that "it has been seriously confounded with "potential", which is almost its contrary. For the potential $\mathrm{X}$ is of the nature of $\mathrm{X}$, but is without actual efficiency. A virtual velocity is something not a velocity, but a displacement; but equivalent to a velocity in the formula, "what is gained in velocity is lost in power" (CP 6.372). In the same year (1902), Peirce defined interpretation including translation as "the sign should, actually or virtually, bring about a determination of a sign of the same object which is itself a sign" so that "there is a virtual endless series of signs when a sign is understood" (MS 599: 30). Virtual reality creates an interpretantsign at runtime efficiency (that is, the pulsant speed of generating a new or renewed interpretant or meaning). Peirce added: "So Milton asks whether the angels have virtual or immediate touch. So, too, the sun was said to be virtualiter on earth, that is, in its efficiency" and he concluded "Virtual is sometimes used to 
as the variety of intersemiosis in operatic signs. The narrative element in opera is a speculative fiction, since it is unclear what is an element, a fragment, and the whole document of opera in itself and its performance. ${ }^{14}$

Finally, let us conclude this essay with some remarks about the signhood of opera. Opera serves as one example of both possible and virtual representation, since operatic "reality" consists in originally cryptic messages which are then enacted on stage. The performance of opera is stylized fictionalized stimulation and enjoyed as such, since modern opera-going audiences enjoy the emotional tension produced by the dramatic harmonies of singing and acting, the vivid orchestration, and theatrical hocus-pocus (Gossett 2006, reviewed by Rosen 2006). The theatrical vision of operatic libretti and its re-enactment on stage form the ultimate multimedia art-form, as an intermedial synchronization of music and drama (Reiss 1971). ${ }^{15}$ Together with other forms of multimedia art, such as theater, cinema, television, ballet, musical, circus, yet different from their specific communication, opera is multichanneled and polysensual communication, and

mean pertaining to virtue in the sense of an ethical habit" (CP 6.372). Peirce stated that the interpretant is not there intellectually, but only in its emotional and bodily value and following an aesthetic, beauty-oriented significance that recommends itself to be perceived by future thought. This development from aesthetics to ethics and logic corresponds to Peirce's First, Second and Third, as well as to Jakobson's distinction, and is no real division. However, a division is appreciated in Greimas's virtualization in narrative semiotics which "corresponds to the act of positing subjects and objects prior to any junction (or, inversely, of purely and simply suppressing this relation)" (Greimas and Courtés 1982: 371).

14 Operatic signs are exemplified in semiotic terms in Hosokawa (1986), also based on the semiotics of theater (Übersfeld 1977). Gorlée (1996 and particularly 1997) discusses the semiotic theory and analysis of Wagner's music drama, Das Rheingold, the beginning opera (Vorabend) of the Ring cycle. Vocal translation of art songs and hymns is approximated in Gorlée (2002, 2005a, 2005b).

15 Reiss (1971: 49-52) introduced the notion of automedial text as a type of mixed text added to ordinary types. She followed Bühler's typology: inhaltsbetonte, formbetonte, and appellbetonte text types (1971: 32 ff.), yet without mentioning Jakobson. The automedial text was propagated by the author (Reiss 1977), reformulated by her into operative text (Reiss 1976: $34 \mathrm{ff}$.) and in semiotic terms (Reiss 1980), but was never adopted within text- and translation studies. Fortunately, the recent English translation (Reiss 2000) of the German Reiss (1971) makes parts of her early work understandable for an "international" audience. 
makes a highly aesthetic rule-governed synchronization of different media of artistic expression. Designed for the ear and the eye (or the eye and the ear, depending on which genre), opera emphasizes the acoustic medium in the form of vocal and orchestral music, together with verbal discourse codified in the libretto. In addition to music, opera highlights visual drama, placed and presented on the operatic scene in the visual-dramatic curtains, lights, movements, gestures, costume, make-up, scenery, and other scenic effects.

The variety of artistic signs in opera produces automedial types. The written signs are not meant to be read but to be sung or recitated in the course of the acoustic and dramatic exposition of the operatic performance. This is true for opera (and opera-like genres such as operetta, oratorio and musical) but also for different but similar literary-gestural genres of intersemiosis, where nonverbal discourses are supposed to be central or rudimentary as opposed to verbal language and the artistic element is degenerate to prepare for Secondness and Thirdness, as found in political speeches, scholarly lectures, and Bible fragments or prayers used liturgically (Gorlée 2005b). The triadic claim of the analysis follows Peirce's interactive categories - Firstness (moodscape), Secondness (worldscape), and Thirdness (mindscape) - to pursue the background of the operatic act, in the act itself, or in its dramatic effect.

To greatly simplify (or oversimplify) a complex textual matter as we experience operatic technology today, an a priori analysis of operatic signhood highlights the following elements of the operatic arena. Jakobson's emotive or expressive function (addresser), the metalingual and conative or appellative values (code and addressee) are the dominant cultural codes, present in the arts of the vocal technique and the interaction of the real (historical or modern) moodscape of the message of the opera visible on stage. Firstness comes to the fore in the poetic modalities of the singing by different singers (aria and especially lyrical and expressive arioso) and the choral singing, in order to "tell" the narrated myth. The singing gestures (Secondness) are an ornamental device but far more radically they are a functional requirement for the "reality" of opera lovers, although the Firstness of music is still commonly the cultural center of the operatic performance, and the signs of Secondness and Thirdness relapse into essential Firstness. 
The (authentic or translated) languages of the sung text in native or foreign text are supposed to be understandable for the addressees. Often, the sung language is mysterious or not understandable through the music. ${ }^{16}$ Many opera singers sing in foreign languages. As a bizarre example, Plácido Domingo has a for him natural Spanish accent in his Wagner pronunciation - a sign of foreignness to the German language, is it to be neglected or given a significance? The non-Italian audience has a hard time understanding Italian text, especially when sung. When the sung language is a linguistic mystery for the opera-goers, theaters are provided with computerized videotapes (supertext, surtitles and subtitles) for projecting captions in the native language as an aid for foreign operas (Rich 1984). If such linguistic aid is not available, the phatic attention of opera lovers is focused away from the language and on to the non-verbal languages used in the performance, namely the aesthetic and artistic characters and designs, transforming and mediating the original libretto into, for the audience, new and exciting transpositions of the story - yet with unchanged music, which is in itself understandable for all listeners.

The Firstness flows over into the performance of Secondness. The addresser is not merely the composer, but the director (impresario) of the renewed opera as first and privileged addressee of the composer (Miller 2001). The opera is meant for a new audience (the real addressees) and the performance and dramatic qualities of the context have changed into modernity. The performed opera is a work of a director, appointed to shift the poetic qualities of the opera, which is often thought of as an archaic piece, to a modern performance. The operatic form and structure presented is now a cryptic outline of the action, available in libretti, score books, and codified dance procedures. These are basic frameworks but the written guides are in desperate need to be expanded on stage to attract as meaningful act of communication the target addressees. ${ }^{17}$ The moodscape of the designed

16 As previously mentioned, see the problems of vocal translation in Gorlée (1996, 1997, 2002, 2005a, 2005b) with an extensive bibliography.

17 Peirce's term was "further developed" when "the sign is interpreted in a sign in your mind", adding that "The whole function of the mind is to make a sign interpret itself in another sign and ultimately perhaps in an action or in an emotion. But the emotion is an idle thing unless it leads to an action. The action is an idle thing unless it produces a result which agrees with a sign through a sign. The whole problem is of signs" (MS 1334: 44). This means that the operatic sign 
operas come to light in the engaged star singers, the orchestra, the chorus, the chosen decoration and ornamentation, etc.; as well as in the directional message of the operatic setting itself: the choice of costumes, composition, rhythmic patterns, sound and light structures, lyrical passages in arias, duets, ensemble singing as well as their orchestral counterparts. Sometimes scenes or actions can be changed (see the case of the two endings in Turandot, one unfinished by Puccini and, after his death, finished by Alfano) or left out. The fragmentary and organized codes require from the singers and chorus a definite temporal and spatial order for the represented operatic events, including movement and gestures of singers and chorus, and the director can make a variety of changes of all kinds - yet the iconic imagery (Gorlée 2005: 66-88) must stay more or less the same or equivalent.

The originally free drama of the opera transpires in the renewed dramatic narrativity of the poetic function and encounters a new referential value from the design. Quoting some sceptical examples: Madama Butterfly displays the love of Cho Cho San for an Englishman, Consul Sharpless, and the story could not be located outside Japanese etiquette; a dislocation would be a nonsensical for the opera goers — and certainly for Puccini; Wagner's The Flying Dutchman displays scenes from a sailor's life, and the opera must be displayed next to the sea to illustrate the long, flowing melody of the stormy waves; and Mussorgski's Boris Godunov is rooted in Russian religious music and iconography during czarism, which can not displaced by "alien" imagery from a later epoch. The examples are socially- and politically-toned: Von Weber's Der Freischutz and Wagner's Die Meistersinger von Nürnberg could easily tone down the German patriotism to please today's political agenda; Mozart's Die Entführung aus dem Serail is a comic opera, part play and part song; this "musical" takes place at a Turkish castle under Pasha Selim, while the harem guard Osmin is made drunk so that the lovers can escape. The charm of the Singspiel can today become hazardous, where Muslim rules are not violated but respected and a change of text and scenery to an "intercultural opera" can be a necessary requirement for a success of the opera. A transposition can affect the narrative plot

develops itself, whereas the director is a silent but hard-working go-between (like an interpreter and translator) of the self-generating sign. See the argument about signs and their own consciousness in Signs Grow by Merrell (1996). 
construction, versificational techniques, and the musical counterpoint, where the source of beauty and aesthetic experience must function in the values today. The performance is the poetic duty of the director, leading the total production of the opera. He (or she) anchors the opera with a new and spectacular show of a flowing pattern of movement of grace and color, and an actual plot or story.

The Firstness and Secondness flow over into the performance of Thirdness in word-and-tone symbiosis. Opera is an essentially unrealistic genre and produces a kind of virtual reality on stage. The artistic poetry seems to neglect the fable, that is, the discourse with recognizable characters, in order to elaborate on the emotions of stock characters appropriate to their words on stage. Yet the informative and situative phatic elements still dominate in recitatives, including similar song forms, such as Sprechgesäng, arias, chorus, as well as speaking parts in spoken dialogue and other moments where the narrative within song takes central stage in music and libretto. Yet the unrealistic thematic and fictive composition differs from the utilitarian in that it is not necessarily suited for any use in the real world. Barthes heralded in 1973 the new opera as a "total spectacle" of theatricality, where he would enjoy "an opera as free and as popular as a movie theater or a wrestling arena: you could go in and out according to your mood, you'd spend part of your evening taking a 'hit' of opera ..." (Barthes 1985: 186). The novel temporal and spatial fictions in the media-rich futurological artistic arena follow these new paths. The new opera in the digital era provides computer-enhanced instruments and synthesizers following virtual opera coextensive with rock, video and film projects. An opera in the imaginary future is no longer a physical or conventional happening in a theater. It no longer has real actors or singers, no real objects on stage, but is provided with sophisticated computer technology for reproducing sound and image. Virtual opera is an imaginary experiment (Thirdness) where the orchestra is replaced by a new combination of acoustic, amplified, and wired instruments and the audience moves around through a threedimensional acoustic space along walkways listening to musical and non-musical fragments (Malitz 1992). ${ }^{18}$ The virtual reality game speaks of the hyperreality of opera, its holographic projection, digital synthesizers, and operatic multimedia computers where the whole

18 For a theory of the concept of "fragment", see Gorlée (2007). 
opera has disappeared and we only listen in cyberspace to computer fragments. The operatic cyberspace describes the simulated "reality" of the parts of opera we enjoy; by worldwide computer networks we hear more violent and realistic hallucinations than offered now in real opera. Neither reality, nor "reality" but pure illusion. ${ }^{19}$

The aesthetic contemplation of opera (Secondness) is contrasted with its representative form of dramatic enlivenment (Thirdness) as emphasized in scenery and machinery on stage, facing the opera aficionados. This co-occurs in Jakobson's addressee's function in its conative/ appellative qualities in association with the phatic quality of fiction, imagination and aesthetics. Opera offers sung dialogue to induce further action, ritualized requests, threats, commands, and instructions that possess real consumer appeal. This attraction happens by accepting the cosmic truths of human life and development, both mythic and contemporary, of opera, describing the Greek epos, ${ }^{20}$ the fusion of epic poetry and musical pathos, in which we seem to take part as addressees. The opera offers an emotional tension for entertainment, which in phatic terms is called the center of vibratory suspense. The catharsis happens by listening and seeing the operatic performance. It produces in the addressees desire, fear and pity, which liberate them from their common reality and displace them into the opera's scenic reality. Catharsis consists in the glossary of word-andtone romantic or tragic qualities, the operatic mystique, fairytaleness, dramatic suspension, and moral atavism, and its dramatic effect signifies a moral cleansing of the (spiritual or mythical) life of the opera lovers. ${ }^{21}$ Catharsis is the principle of Peirce's infinite semiosis, meaning an "inner song to sing against despair" (Shipley 1972: 50).

19 Gibson coined the name of cyberspace in his famous novel Neuromancer (Gibson 1984); see Rheingold's Virtual Reality (Rheingold 1991) and (already mentioned) Moulthrop 1991.

20 Shipley (1972: 139) mentioned classical Greek "epos" meaning "word", then a "speech or tale" and a "song", and subsequently "a heroic poem" and "heroic poetry" advancing the later epics of the Middle Ages (Beowulf, the Song of Roland, the Nibelungenlied, etc.) irrespective of classical models.

21 This general classification matches Peirce's triplet of tone, token, and type (corresponding to qualisign, sinsign, and legisign and Firstness, Secondness, and Thirdness) (Freadman 1993: 89f.). For tone, e.g., CP 4.537, 8.363, token CP $3.360,4.537,8.363 \mathrm{ff}$., type CP 4.537, 8.363. Peirce wrote in his Logic Notebook (1865-1909), on a handwritten memo written on 8 July 1906, that "A Tone as that whose accidental being makes it a sign. A Token or that whose accidents of 
A strain of music or mindscape is an individual semiotic reality, including an ideology involved in the categorical elements. It is firstly a moodscape, a sensation-seeking sign, then a worldscape showing musical reality and suggesting the dynamism of chaos and leading to some order. In the Peircean kaleidoscope, the so-called mindscape is more than to be taken by the listeners (addressees or receivers) as an expressive conception of the holding-over of a note, chord, and melody together with word, phrase, and myth from one tuned melody of completeness to the next. The design and direction of the opera could develop a Freudian, Marxist, feminist, or any other ideological dimension or specific outlook. Peirce would say that the meaning of the opera "grows" 22 when put on stage.

The whole generation after Wagner is formulated by his new concept of leitmotivs with their harmonic rather than linear development (Gorlée 1997: 249) and associated with a specific idea, concept, mood of individual. Examples are from Wagner's Die Walküre, the Motiv-Tafel of e.g., musically recognizable Entsagung-, Fluch-, Nibelungenhass-, Schicksal-, Sturm-, Unruhe-, and Verzweiflungsmotiv (list of tables in Wagner 1908: intro). In concert with words leitmotivs equally express condensed feeling, such operatic signs were transformed into powerful musical phrases or fragments, which, once introduced, were repeated many times during the opera, modified by

existence make it a sign. A Type or that thought upon which makes it a sign" (MS 339C: 499). This triad pertains to notational systems as written signs: a tone embodies material properties, a token signifies the condition of their action, a type is a significant form produced affecting musical notation: the pictorially symbolic and graphic system of arbitrary signs indicating pitch, duration and song (or score). In music, the triad tone, token and type affect the categorical elements of expression, tempo and nuance with rhythms, harmony and tune.

22 Peirce used the botanical term of growth as such and in general terms, including fine arts. For some examples: CP 2.302, 5.594 and applied by Peirce in the "cosmological or secular character of philosophy" (CP 1.177) stating that philosophy applied to other arts has an "architectonic character" (heading of CP 1.176). Peirce added that "philosophy is a thing that has to grow by the fission of minute parts and not by accretion is due the necessity of planning it out from the beginning. Of course, every painting likewise has its composition; but composition is not a very weighty problem, except in that kind of painting which is accessory to architecture, or is, at any rate, very public in its appeal. Indeed historical painting is one of those exceptions which go to prove the rule that in works which aim at being secular, rather than individualistic, the preliminary business of planning is particularly important and onerous" (CP 1.177). 
modulation and interpretation to explore the full meaning-potential of the poetic-melodic-harmonic universe in all its proportions and depth. Consequently, the fragment and the continuous can no longer be neatly delimited in the Wagnerian discourse, where a dissonance and a delay of the tonal resolution and identity of motives remain "in the air", a clue of the intertextuality and intermediality of Wagner's melos. The worldscape kind of music and poetic transitions allude to an interwoven thread of replicating motives and themes in order to build the argumentative development of the whole opera.

The semiotic viewpoints used in this article are the basic framework of my work on the translation of opera libretti, lyrical art songs, and church hymns (Gorlée 1996, 1997, 2002, 2005b), introduced by a theoretical model (Gorlée 2005a) dealing with the unresolvable paradoxes of the word-tone symbiosis to serve the modernity of translationese. The originally free drama of the opera transpires in the renewed dramatic narrativity of the poetic function and encounters a new referential frame from the design which would deserve further investigation. Jakobson's functional models have been linked with Peirce's categories and applied to the tonal and musical relevance for the audiovidual artforms and the intralingual, interlingual, and intersemiotic translations. To resolve these riddles of transposing from one language and culture to another, new translational paradigms are articulated, giving rise to reborn ideas and a renewed culture, readapting operatic signs in terms of emotion, time and circumstance and stimulated artistically, dynamically, and scholarly.

\section{References}

Andrews, Edna 1999. Lotman's communication act and semiosis. Semiotica 126(1/4): 1-15.

Auerbach, Erich 1957 [1946]. Mimesis: The Representation of Reality in Western Literature. [Trans. William Trask.] Garden City: Doubleday \& Company. [First German edition - Dargestellte Wirklichkeit in der abendländischen Literatur. Bern: Francke, 1946; first English transl. Princeton: Princeton University Press, 1953.]

- 1959. Figura. In: Auerbach, Erich, Scenes from the Drama of European Literature. [Trans. Ralp Manheim.] New York: Meridian Books, $11-76$. 
Barthes, Roland 1985. The phantoms of the opera. In: Barthes, Roland, The Grain of the Voice: Interviews 1962-1980. London: Jonathan Cape, 183-187. [Transl. Linda Coverdale; from an interview for $L e$ Nouvel Observateur, 17 December 1973.]

Bühler, Karl 1990. Theory of Language: The Representational Function of Language. (Foundations of Semiotics 25.) Amsterdam and Philadelphia: John Benjamins Publishing. [Transl. Donald Fraser Goodwin; German original: Sprachtheorie - Die Darstellungsfunktion der Sprache. Jena: Gustav Fischer, 1934.]

CP = Peirce, Charles Sanders (1931-1966). Hartshorn, Charles; Weiss, Paul and Burks Arthur W. (eds.), Collected Papers of Charles Sanders Peirce. 8 vols. Cambridge: Belknap Press of Harvard University Press. [In-text references are to $\mathrm{CP}$, followed by volume and paragraph numbers.]

Derrida, Jacques 1987. The Postcard from Socrates to Freud and Beyond. Chicago: The University of Chicago Press. [Transl. Alan Bass; French original: La carte postale de Socrate à Freud et au-delà. Paris: Flammarion, 1980.]

Dirda, Michael 2007. Dante: The supreme realist. The New York Review of Books 54(1): 54-55, 58.

Eschbach, Achim (ed.) 1984. Bühler-Studien. (Suhrkamp Taschenbuch Wissenschaft 481/482.) 2 vols. Frankfurt am Main: Suhrkamp Verlag.

Freadman, Anne 1993. Music "in" Peirce. Versus 64: 75-95.

Gibson, William 1984. Neuromancer. New York: Ace Books.

Gorlée, Dinda L. 1988. Signs and magic in Don Quijote de la Mancha. Neophilologus 72: 56-65.

- 1990. Degeneracy: A reading of Peirce's writing. Semiotica 81(1/2): 71-92.

- 1994. Semiotics and the Problem of Translation, With Special Reference to the Semiotics of Charles S. Peirce. (Approaches to Translation Theory 12.) Amsterdam and Atlanta: Rodopi.

- 1996. Opera translation: Charles Peirce translating Richard Wagner. In: Tarasti, Eero (ed.), Musical Semiotics in Growth. (Acta Fennica 4.) Bloomington: Indiana University Press and Imatra: International Semiotics Institute (ISI), 413-441.

- 1997. Intercode translation: Words and music in opera. Target 9(2): $235-270$.

- 2002. Grieg's swan songs. Semiotica 142(1/4): 142-210.

- 2004a. Translation as a semiotic problem, including intersemiotic translation. In: Kittel, Harald; Frank, Armin Paul; Greiner, Norbert; Hermans, Theo; Koller, Werner; Lambert, José; Paul, Fritz (eds.), 
Übersetzung Translation Traduction. Ein internationales Handbuch zur Übersetzungsforschung. An international Encyclopedia of Translation Studies. Encyclopédie internationale de la recherche sur la traduction. Vol.1. Berlin and New York: Walter de Gruyter, 53-61.

- 2004b. On Translating Signs: Exploring Text and Semio-Translation. (Approaches to Translation Studies 24.) Amsterdam and New York: Rodopi.

- 2005a. Prelude and acknowledgements. In: Gorlée, Dinda L. (ed.), Song and Significance: Virtues and Vices of Vocal Translation. (Approaches to Translation Theory 25.) Amsterdam: Rodopi, 7-15.

- 2005b. Singing on the breath of God: Preface to life and growth of translated hymnody. In: Gorlée, Dinda L. (ed.), Song and Significance: Virtues and Vices of Vocal Translation. (Approaches to Translation Theory 25.) Amsterdam: Rodopi, 17-101.

- 2007. Broken signs: The architectonic translation of Peirce's fragments. Semiotica 163(1/4): 209-287.

Gossett, Philip 2006. Divas and Scholars: Performing Italian Opera. Chicago: The University of Chicago Press.

Greimas, Algirdas-Julien; Courtés, Joseph 1982. Semiotics and Language: An Analytical Dictionary. (Advances in Semiotics.) Bloomington: Indiana University Press. [Transl. Larry Crist, Daniel Platte et. al.; French edition - Semiotique: Dictionnaire raisonné de la théorie du language. Paris: Hachette, 1979.]

Hess-Lüttich, Ernest W. B. 1986. Multimedia communication. In: Sebeok, Thomas A. (gen. ed.), Encyclopedic Dictionary of Semiotics. (Approaches to Semiotics 73.) Berlin: Mouton de Gruyter, vol. 2, 573-577.

Hosokawa, Shuhei 1986. Opera. In: Sebeok, Thomas A. (gen. ed.), Encyclopedic Dictionary of Semiotics. (Approaches to Semiotics 73.) Berlin: Mouton de Gruyter, vol. 2, 649-651.

Jakobson, Roman 1959. On linguistic aspects of translation. In: Brower, Reuben A. (ed.), On Translation. New York: Oxford University Press, 232-239.

- 1960. Concluding statement: Linguistics and poetics. In: Sebeok, Thomas A. (ed.), Style in Language. Cambridge: MIT Press, 350-377.

- 1971a. Language in relation to other communication methods. In: Jakobson, Roman, Selected Writings. Vol. II World and Language. The Hague: Mouton, 697-708.

- 1971b. Results of a joint conference of anthropologists and linguistics. In: Jakobson, Roman, Selected Writings. Vol. II World and Language. The Hague: Mouton, 554-567. 
- 1980. Metalanguage as a linguistic problem. In: Jakobson, Roman, The framework of Language. (Michigan Studies in the Humanities.) Ann Arbor: University of Michigan, 81-92. [Irwin R. Titunik and Ladislav Matejka, eds.]

Koller, Werner 1992. Einführung in die Übersetzungswissenschaft. (UniTaschenbücher 819.) Heidelberg: Quelle \& Meyer.

Lotman, Yuri M. 1990. Autocommunication: 'I' and "other" as addressees. In: Lotman, Yuri M., Universe of the Mind: A Semiotic Theory of Culture. [Trans. Ann Shukman.] London: Taurus, 20-35.

Malinowski, Bronislaw 1969. The problem of meaning in primitive language. In: Ogden, Charles Kay; Richards, Ivor Armstrong (eds.), The Meaning of Meaning: A Study of the Influence of Language upon Thought and of the Science of Symbolism. London: Routledge \& Kegan Paul, Supplement I: 296-336. [1st ed. 1923.]

Malitz, Nancy 1992. HyperReality. Opera News 57(2): 28-30.

Maran, Timo 2003. Mimesis as a phenomenon of semiotic communication. Sign Systems Studies 31(1): 191-215.

Merrell, Floyd 1992. Film and book: Comparative modes of perception. In: Dispositio 15(40): 141-150.

- 1996. Signs Grow: Semiosis and Life Processes. (Toronto Studies in Semiotics.) Toronto: University of Toronto Press.

Miller, Jonathan 2001. Doing Opera. In: Silvers, Robert B. (ed.), Doing It: Five Performing Arts. New York: New York Review of Books, 47-69. [First ed. in 2000, The New York Review of Books 47(8): 1216.]

Moulthrop, Stuart 1991. Paragnosis: The hermeneutic of resistance in cyberspace. Semiotische Berichte 15(4): 397-413.

MS $=$ Peirce, Charles Sanders. Unpublished manuscripts. Copies from Peirce Edition Project of Indiana University-Purdue University, Indianapolis. [In-text references are to MS, followed by manuscript number and page numbers.]

Munro, Thomas 1969. The Arts and Their Interrelations. Cleveland: The Press of Case Western Reserve University.

Nöth, Winfried 1990. Handbook of Semiotics. (Advances in Semiotics.) Bloomington and Indianapolis: Indiana University Press Company [Transl. Winfried Nöth; 1st German ed. Handbuch der Semiotik. Stuttgart: J. B. Metzlersche Verlagbuchhandlung, 1985].

Plaza, Julio 1985. Sobre tradução intersemiótica. Unpublished Ph.D. thesis of Pontificial Catholic University of São Paulo.

- 1987. Tradução intersemiótica. (Estudos 93.) São Paulo: Editora Perspectiva. 
- 1991. Reflection of and on theories of translation. Dispositio 6(17/18): 45-91.

Popovič, Anton 1975. Dictionary for the Analysis of Literary Translation. Edmonton: University of Alberta, Department of Literary Translation. [Machine-written document.]

Rheingold, Howard 1991. Virtual Reality. New York: Summit Books.

Reiss, Katharine 1971. Möglichkeiten und Grenzen der Übersetzungskritik: Kategorien und Kriterien für eine sachgerechte Beurteilung von Übersetzungen. (Hueber Hochschulereihe 12.) München: Max Hueber.

- 1976. Texttyp und Übersetzungsmethode - Der operative Text. Kronberg, Ts.: Scriptor Verlag. [2nd unchanged edition published in Heidelberg: Julius Groos Verlag, 1983.]

- 1977. Texttypen, Übersetzungstypen und die Beurteilung von Übersetzungen. Lebende Sprachen 3: 97-100.

- 1980. Zeichen oder Anzeichen? Probleme der AS-Textanalyse im Blick auf die Übersetzung. In: Wilss, Wolfram (ed.), Semiotik und Übersetzen. (Kodikas/Code, Supplement 4.) Tübingen: Gunter Narr Verlag, 63-72.

- 2000. Translation Criticism - The Potentials \& Limitations: Categories and Criteria for Translation Quality Assessment. [Trans. Erroll Rhodes.] Manchester: St. Jerome Publishing and New York: American Bible Society.

Rich, Maria F. 1984. Opera titles go live. The Opera Quarterly 2: 77-87.

Rosen, Charles 2006. Opera: Follow the music. The New York Review of Books 63(15): 36-38.

Sager, J. C. 1986. Die Übersetzung im Kommunikationsprozeß. In: SnellHornby, Mary (ed.), Übersetzungswissenschaft - eine Neuorientierung. Zur Integrierung von Theorie und Praxis. Tübingen: Francke, 331-347.

Scholes, Robert 1992. Canonicity and textuality. In: Gibaldi, Joseph (ed.), Introduction to Scholarship in Modern Languages and Literatures. New York: The Modern Language Association of America (MLA), $138-158$.

Shipley, Joseph T. (ed.) 1972. Dictionary of World Literature: Criticism - Forms - Technique. Totowa: Littlefields, Adams \& Co.

Torop, Peeter 1995. Total'nyj perevod. Tartu: Tartu University Press. [ $\mathrm{La}$ traduzione totale, transl. Bruno Osimo. Modena: Guaraldi, 2000.]

- 2000. Intersemiosis and intersemiotic translation. European Journal for Semiotic Studies 12(1): 71-97. 
- 2003. Intersemiosis and intersemiotic translation. In: Petrilli, Susan (ed.), Translation Translation. (Approaches to Translation Studies 21.) Amsterdam: Rodopi, 272-282.

Toury, Gideon 1986. Translation: A cultural-semiotic perspective. In: Sebeok, Thomas A. (gen. ed.), Encyclopedic Dictionary of Semiotics. (Approaches to Semiotics 73.) Berlin: Mouton de Gruyter: vol. 2, 1111-1124.

Übersfeld, Anna 1977. Texte-représensation. In: Übersfeld, Anna, Lire le théâtre. Paris: Editions Sociales, 13-52.

Wagner, Richard 1908. Die Walküre, Karl Klindworth (piano score). Mainz: B. Schott's Söhne. [Written in 1854-1856, first performance 1870.]

\section{Якобсон и Пирс: переводческий интерсемиозис и симбиоз в опере}

Метаязыковые операции обозначают понимание и акт перевода, как они определены Якобсоном в его моделях шести языковых функций и трех типов перевода, которые обе были созданы в 1950-е годы. Настоящая статья основывается на этих моделях Якобсона, связывая их с тремя категориями Пирса. Три основывающиеся на качественном различии функции Бюлера стали предшественниками (скорее всего не случайно) дистинкций Якобсона, которые указывают на квантитативные различия между формами и структурами различных видов искусств. Семиотическое открытие, критика и перспектива рассмотрения элементов и единиц кода так же устанавливают квантитативные различия, как и различия между реалистичными сообщениями и концептуальными кодами. Якобсоновскому понятию интерсемиотического перевода дает новое содержание анализ вокального перевода, который занимается виртуальной реальностью на оперной сцене. Синтез слова и звука (или семиозисный симбиоз) в опере демонстрирует типологическую унификацию вербальных и невербальных языков. 


\section{Jakobson ja Peirce: tõlkeline intersemioos ja sümbioos ooperis}

Metakeelelised operatsioonid tähistavad arusaamist ja tõlkeakti, nii nagu neid on määratlenud Jakobson oma kuue keelefunktsiooni ja kolme tõlketüübi mudelis, mis mõlemad pärinevad 1950ndatest aastatest. Käesolev artikkel tugineb neile Jakobsoni mudelitele, seostades neid Peirce'i kolme kategooriaga. Bühleri kvalitatiivsel erinevusel põhinevad kolm funktsiooni olid (võib-olla mitte juhuslikult) eelkäijaks Jakobsoni eristustele, mis viitavad kvalitatiivsetele erinevustele erinevate kirjandus- ning ka teiste kaunite kunstide vormide ja struktuuride vahel. Kvantitatiivse erinevuse ning erinevuse realistlike sõnumite ja kontseptuaalsete koodide vahel määrab semiootiline avastus, kriitika ning vaatepunkt, mis eristab keeleelemente koodiühikutest. Jakobsoni intersemiootilise tõlke mõistele pakub uut sisu vokaalse tõlke analüüs, mis tegeleb ooperliku müstika kaudu katarsisesse jõudva virtuaalse reaalsusega ooperilaval. Ooperi sõna-heli süntees (ehk semioosiline sümbioos) osutub nähtuseks, mis ühendab verbaalsed ja mitteverbaalsed keeled tüpoloogiliselt. 